\title{
Quantitative Assessment of Some Toxic Elements and Physicochemical Parameters in Wastewater of Dyeing Industry: A Case Study
}

\author{
Ghulam Mustafa Channa ${ }^{1 *}$, Jameel Ahmed Baig ${ }^{1}$, Imam Bakhsh Solangi², \\ Tasneem Gul Kazi ${ }^{1}$, Hassan Imran Afridi ${ }^{1}$ and Muhammad Waris ${ }^{1}$ \\ ${ }^{1}$ National Center of Excellence in Analytical Chemistry, University of Sindh, Jamshoro, Pakistan. \\ ${ }^{2}$ Dr. M.A. Kazi Institute of Chemistry, University of Sindh, Jamshoro, Pakistan. \\ *Corresponding Author Email: gmchanna139@gmail.com \\ Received 22 July 2019, Revised 13 June 2020, Accepted 15 June 2020
}

\begin{abstract}
The current study aims to examine the concentration of some toxic elements such as, cadmium $(\mathrm{Cd})$, chromium $(\mathrm{Cr})$, lead $(\mathrm{Pb})$ and nickel $(\mathrm{Ni})$ and physicochemical parameters such as electric conductivity (EC), $\mathrm{pH}$, total dissolved solids (TDS), and biological oxygen demand (BOD) in the wastewater of dye manufacturing, textile dyeing, and small dyeing industries. The concentrations of $\mathrm{Cd}, \mathrm{Cr}$, and $\mathrm{Ni}$ in wastewater samples of these industries were significantly higher than the permissible limits set by WHO for toxic metals in industrial wastewater. The highest level of EC was observed in wastewater samples of the small dying industry as compared to the other two types of industries. The BOD of the investigated wastewater samples was almost two to threetimes exceeded than the suggested threshold level recommended by EPA for industrial wastewater. The elevated BOD levels might be due to the presence of the excess level of organic matter in wastewater discharged from the various activities of industries.
\end{abstract}

Keywords: Wastewater, Dyeing industry, Toxic metals, Physicochemical parameters

\section{Introduction}

Fast societal advancement and growth in the domain of science and technology led to the modern age. However, the global pollution created by these advancements can lead to paying for them [1]. Domestic and industrial waste management is a big issue for developing nations. The direct disposed of these wastes in a nearby water body without proper treatment is common practice in some countries. As a result, our natural freshwater reservoirs such as canals, lakes, and rivers are severely contaminated. Thus, these are not safe for industrial and residential purposes [2]. Pakistan included in those countries which may have these all crisis of environmental contamination, this might be due to densely populated cities. The consumption of freshwater resources for drinking and other activities remains a common practice in our country. However, these are intensely contaminated [3]. The river-based irrigation system of Pakistan considered the most productive system in the world. But it is contaminated by domestic and industrial wastewater. The toxicants may have redundantly affected the biological, chemical, and physical quality of natural water resources $[4,5]$. The facts indicated that the common physiological and environmental consequences are obvious such as the effluents of different industries that contain dangerous chemicals, toxic metals, dyes, and pathogenic nature in wastewater that makes natural water contaminated when discharged into natural water bodies [6]. Especially, the wastewater of dye manufacturing and textile dyeing industries can significantly alter the physicochemical 
characteristics and toxic metals $(\mathrm{Cr}, \mathrm{Cd}, \mathrm{Pb}$, and $\mathrm{Ni}$ ) in river water. The increase in the BOD of river water is most probably due to the biodegradable organic wastes [7]. This may come from different industries such as fertilizer industries make use of chemical for fumigation and pest control products, pharmaceutical industries uses biological active compounds in different drugs, textile, food, leather, paper and plastic industries use different natural pigments for enhancing the color of products thus when effluent of these industries are discharged into water bodies it alters the nature of water [8-11]. The presence of toxic metals in the water can pose adverse effects on humans, flora, and fauna [12$14]$.

Thus, if we talk about treatment technology of the polluted/wastewater so there are many advanced treatment technologies for polluted/wastewater which make it drinkable. Several advanced methods have been focused on the removal of toxic metals, dyes, and other pollutants, such as adsorption, photocatalytic degradation, foam floatation, osmosis, biological methods, membrane process, dialysis and coagulation methods [15]. Since the complex nature of different mixtures of chemical present in wastewater, public wastewater treatment of removal of entire contaminants consignment is not always adequate. Humanoid pathogens are also controlled by fumigation steps such as chlorination and ozonation. Many chemicals, toxic metals, dyes used in food and textiles, and unwanted pathogens are effectively eliminated by these advanced processes of treatment [16]. A low-cost, semiconductor photocatalytic process sustainable and environmentally friend method is being focused by the industries to line up with the scheme of "zero" waste in the effluent of the industry [17]. Thus, the persistent toxic metals such as arsenic metal ions, organic compounds, and other microorganisms are removed from the wastewater by this advanced oxidation technology. Academic researchers and different industries extensively believe in one of the most effective advanced technology of the polluted water treatment processes for the removal of pollutants that technology is "Adsorption". One of the most commonly used water treatment technology as adsorbent is activated carbon [18].
In recent years by using biomaterials as the adsorbents for the treatment of polluted water, adsorption technology has become popular and taken great attention by industries and academic scientists $[19,20]$. Because of the use of different complex chemicals, toxic metals, dyes, and biological agents the nature of pollutant become different for that different advanced techniques are introduced and employed to treat polluted water. The cost always increases to get clean water by this invariably. Operation cost may also matter when such technologies have to reach in underdeveloped countries especially to poor people, where water shortage is also common. However, knowledge about safe water is still not satisfactory for people around the world.

Dyes are mainly used as colorant by many industries such as textile, pharmaceutical, plastic, paper, cosmetics, food industries, etc. [21-24]. The basic characteristics which attracts the consumers regarding product selection are the attractive color, design, good fixation of color with light, dampness and washing, etc. so the dying process is very important sector of these industries. For successful trading of products, the dying process play very important role in these industries. In Pakistan, either these industries may have not these safety precautions/remediation systems, or these may not be functional to save the money. To keep in view of the said facts, the current study designed to examine some of the toxic metals and physicochemical parameters of wastewater of three types of dyeing industries.

\section{Materials and Methods Sample collection}

Random samples of industrial wastewater were collected from thirty-eight industries of the industrial site areas of Hyderabad, and Jamshoro Sindh, Pakistan. The industries are divided into three categories based on manufacturing and usage of dyes, as dye manufacturing industries (DMI), textile dyeing industries (TDI) and small dyeing industry (SDI). Wastewater of DMI $(n=8)$, TDI $(n=12)$ and SDI $(n=18)$ were collected from discharging point of each industry in $1000 \mathrm{~mL}$ plastic bottles. Then, half portion of each collected samples were used to test four quality parameters including biochemical oxygen demand (BOD), total dissolved solids (TDS), $\mathrm{pH}$ and electric 
conductivity (EC). The remaining half portion of collected wastewater samples were used to determined toxic metals by using conventional pre-concentration method as reported elsewhere [1].

\section{Chemicals and reagents}

High-purity water was used during the experiment, got from a Millipore Corp, Milli-Q purifier system (Bedford, MA, USA). The analytical grade reagent concentrated $\mathrm{HNO}_{3}(65 \%)$ and $\mathrm{H}_{2} \mathrm{O}_{2} \quad(30 \%)$ were obtained from Merck (Darmstadt, Germany). The working standard solutions of $\mathrm{Cd}, \mathrm{Cr}, \mathrm{Ni}$, and $\mathrm{Pb}$ made freshly in dynamic range by appropriate dilution of $10 \mathrm{mg}$ $\mathrm{L}^{-1}$ stock solution in $0.2 \mathrm{~mol} / \mathrm{L}$ of $\mathrm{HNO}_{3}$, prepared from certified standard solutions (1000 $\left.\mathrm{mg} \mathrm{L}^{-1}\right)$ of corresponding metals procured from Fluka Kamica (Buchs, Switzerland).

\section{Instrumentation}

The study of the selected toxic metals was done by using the atomic absorption spectrometer (AAS), Hitachi (Tokyo, Japan). The hollow cathode lamps of toxic metals assembled to AAS along with the graphite atomizer. The determinations of toxic metals were performed according to the manual as reported elsewhere [1-3]. Details of instrumental settings and temperature programing for each toxic metal are listed in Table 1.

Table 1. Measurement conditions for toxic elements by AAS.

\begin{tabular}{|c|c|c|c|c|}
\hline Parameter & Cd & $\mathrm{Cr}$ & $\mathrm{Ni}$ & $\mathbf{P b}$ \\
\hline $\begin{array}{l}\text { Lamp current } \\
(\mathrm{mA})\end{array}$ & 7.5 & 7.5 & 10 & 7.5 \\
\hline $\begin{array}{l}\text { Wavelength } \\
(\mathrm{nm})\end{array}$ & 228.8 & 357.9 & 232.0 & 283.3 \\
\hline Slit-width (nm) & 1.3 & 1.3 & 0.2 & 1.3 \\
\hline Cuvette & Cup & Tube & Tube & Cup \\
\hline Dry $^{a}$ & $\begin{array}{c}80- \\
120 / 15\end{array}$ & $\begin{array}{c}80- \\
120 / 15\end{array}$ & $\begin{array}{c}80- \\
120 / 15\end{array}$ & $\begin{array}{c}80- \\
120 / 15\end{array}$ \\
\hline $\mathrm{Ash}^{\mathrm{a}}$ & $\begin{array}{c}300- \\
600 / 15\end{array}$ & $\begin{array}{c}300- \\
700 / 15\end{array}$ & $500-700 / 15$ & $\begin{array}{c}300- \\
600 / 15\end{array}$ \\
\hline Atomization $^{\mathrm{a}}$ & $\begin{array}{l}1500- \\
1800 / 5\end{array}$ & $\begin{array}{c}2600- \\
2700 / 5\end{array}$ & $\begin{array}{l}2500- \\
2600 / 5\end{array}$ & $\begin{array}{c}2000- \\
2100 / 5\end{array}$ \\
\hline Cleaning $^{\mathrm{a}}$ & $\begin{array}{c}1800- \\
2000 / 2\end{array}$ & $\begin{array}{c}2700- \\
2900 / 2\end{array}$ & $\begin{array}{c}2600- \\
2800 / 2\end{array}$ & $\begin{array}{l}2100- \\
2400 / 2\end{array}$ \\
\hline $\begin{array}{l}\text { Chemical } \\
\text { Modifier }\end{array}$ & $\begin{array}{c}\mathrm{Mg}\left(\mathrm{NO}_{3}\right)_{2}+ \\
\mathrm{Pd}\left(\mathrm{NO}_{3}\right)_{2}\end{array}$ & $\mathrm{Mg}\left(\mathrm{NO}_{3}\right)_{2}$ & $\mathrm{Mg}\left(\mathrm{NO}_{3}\right)_{2}$ & $\mathrm{Mg}\left(\mathrm{NO}_{3}\right)_{2}$ \\
\hline
\end{tabular}

\section{Analytical figure of merits and Statistical evaluation}

The calibration of successive diluted certified standards was obtained based on the linear regression analysis and resulted data is listed in Table 2. The limit of detection (LOD) and limit of quantitation (LOQ) were estimated by multiplying the three and ten, respectively with the ratio of the standard deviation of ten blank readings and slope of the calibration curve (signal to noise ratio). Due to the absence of certified reference materials for wastewater, the validity of the analytical method was performed on replicate six subsamples of wastewater, spiking with three concentration levels of $\mathrm{Cd}, \mathrm{Cr}, \mathrm{Ni}$, and $\mathrm{Pb}$. The recoveries of $\mathrm{Cd}, \mathrm{Cr}, \mathrm{Ni}$, and $\mathrm{Pb}$ were generally greater than 97\% (Table 3). It was seen that the good agreement between the spiked and the obtained contents of $\mathrm{Cd}, \mathrm{Cr}, \mathrm{Ni}$, and $\mathrm{Pb}$ in the wastewater. The certainty of the method was quantified by using the triplicate subsamples of each reagent blank, standard reference material, and wastewater samples. Excel 365 (Microsoft Office (®) used to compile the data and statistical analysis. Evaluation of variations amongst the levels of toxic metals in wastewater samples of dyeing industries intended by the t-test. And $(\mathrm{p}<0.05)$ was measured substantial alteration.

Table 2. Slope and intercepts with linear regression lines of concentration versus absorption data of standard solutions of different element.

\begin{tabular}{|c|c|c|c|c|}
\hline Element & $\begin{array}{c}\text { Dynamic } \\
\text { Range } \\
(\mu \mathrm{g} / \mathrm{L})\end{array}$ & $\begin{array}{c}\text { Regression } \\
\text { equation }\end{array}$ & $\mathbf{R}^{2}$ & $\begin{array}{c}\text { LOD/LOQ } \\
(\mu \mathrm{g} / \mathrm{L})\end{array}$ \\
\hline $\mathrm{Cd}$ & $200-1000$ & $\begin{array}{c}y=5.8 \times 10^{-3} \\
(\mathrm{Cd})+3.0 \times 10^{-4}\end{array}$ & 0.999 & $0.327 / 1.09$ \\
\hline $\mathrm{Cr}$ & $50-500$ & $\begin{array}{c}y=5.0 \times 10^{-4} \\
(\mathrm{Cr})+2.3 \times 10^{-3}\end{array}$ & 0.998 & $4.70 / 15.8$ \\
\hline $\mathrm{Ni}$ & $100-2000$ & $\begin{array}{c}y=3.0 \times 10^{-4} \\
(\mathrm{Ni})+3.0 \times 10^{-4}\end{array}$ & 0.999 & $6.67 / 22.2$ \\
\hline $\mathrm{Pb}$ & $50-500$ & $\begin{array}{c}y=7.0 \times 10^{-4} \\
(P b)+8.0 \times 10^{-4}\end{array}$ & 0.999 & $3.38 / 11.3$ \\
\hline
\end{tabular}


Table 3. Analytical results of toxic metals in real sample of effluents by standard addition method by conventional Preconcentration.

\begin{tabular}{cccc}
\hline Metals & $\begin{array}{c}\text { Added conc. } \\
(\mathbf{m g} / \mathbf{L})\end{array}$ & $\begin{array}{c}\text { Obtained } \\
\text { Concentration }\end{array}$ & $\begin{array}{c}\text { (\%) } \\
\text { Recovery }\end{array}$ \\
\hline \multirow{3}{*}{$\mathrm{Cd}$} & 0 & 0.002 & -- \\
& 0.25 & 0.251 & 99.6 \\
& 0.50 & 0.497 & 99.0 \\
$\mathrm{Cr}$ & 0 & 0.031 & -- \\
& 1 & 1.02 & 98.9 \\
& 2.5 & 2.53 & 99.96 \\
$\mathrm{Ni}$ & 0 & 2.39 & -- \\
& 1 & 3.37 & 98 \\
& 2.5 & 4.83 & 97.6 \\
$\mathrm{~Pb}$ & 0 & 0.021 & -- \\
& 0.25 & 0.266 & 98.2 \\
\hline
\end{tabular}

\section{Results and Discussion}

In studied DMI, TDI, and SDI effluent samples, the temperature showed a very characteristic annual cycle, with higher values during the summer $\left(28-45^{\circ} \mathrm{C}\right)$ and lower values in the winter season $\left(18-25{ }^{\circ} \mathrm{C}\right)$. However, the sampling of the industrial effluents was performed in summer (during July and August) in between 8 to 9 am $\left(28-30{ }^{\circ} \mathrm{C}\right)$. Therefore, the impact of evaporation on the collected effluent samples may not be showing a great variation in measurements of physicochemical parameters and the concentration toxic metals $(p<0.05)$. The resulted data of physicochemical parameters ( $\mathrm{pH}$, TDS, $\mathrm{EC}$, and BOD) of studied composite industrial effluent samples of three types of industries are given in Fig. 1 and Fig. 2. The $\mathrm{pH}$ of effluent samples of DMI, TDI, and SDI wastewater samples were found in the range of 6.80-10.1, 7.30-7.70, and 7.20-9.70, respectively (Fig. 1). The $\mathrm{pH}$ of all studied industrial wastewater samples were neutral to basic, this might be due to the presence of different chemicals used in cleaning, color sticking, mordant, washing and polymerization/dying process in these industries [25-28]. Azeem et al., (2009) has explained that the alkaline $\mathrm{pH}$ of natural water may be affecting on the fish including damage to outer surfaces like gills, eyes, skin, and an inability to dispose of metabolic wastes [29]. Moreover, the high $\mathrm{pH}$ of industrial wastewater samples may also increase the toxicity of other substances [30]. Whilst, EC of studied effluent samples of DMI, TDI, and SDI were observed in between 0.962-2.86, 0.1010.584 , and $0.835-3.51 \mathrm{mS} \mathrm{cm} \mathrm{cm}^{-1}$, respectively (Fig. 1). The range of TDS in effluent samples of DMI, TDI, and SDI was found in the range of 5571133 , 356-450, and 399-1168 $\mathrm{mg} \mathrm{L}^{-1}$, respectively (Fig. 2). The TDS and EC of TDI effluent samples were lower than DMI and SDI, which might be due to the huge volume of water used for washing. The elevated contents of EC in DMI and SDI wastewater samples may be attributed to the high salinity and mineral contents in nearby water bodies. The EC provides the information about the dissociated and dissolved substances based on the concentration, degree of dissociation of ions and the temperature [31,32]. The EC of understudy types of industrial wastewater samples were found to be higher than the US-EPA permissible limits (1.00 $\mathrm{mS} \mathrm{cm}^{-1}$ ) except TDI effluent samples [33]. The EC of TDI effluent samples were found to be low as compared to wastewater samples of the other three industries $(\mathrm{p}>0.05)$. The maximum level of EC was observed in effluent samples of SDI followed by DMI. It is because of the release of different chemical compound along with dyes into their wastewater samples and may cause of deterioration of drinking water quality [34,35]. These industries discharged a high amount of chemical, biochemical, and solid waste without proper treatment and directly introduced into natural water bodies like rivers and canals (Fig. 3). These may directly or indirectly become the cause of several environmental and health consequences.

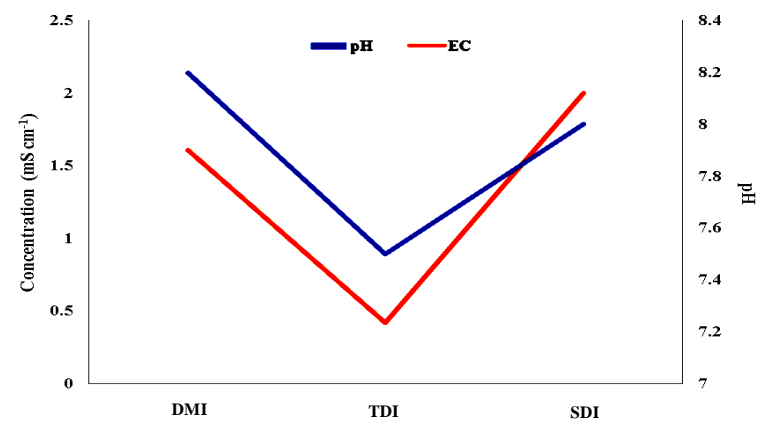

Figure 1. pH and EC of different industrial effluents samples 


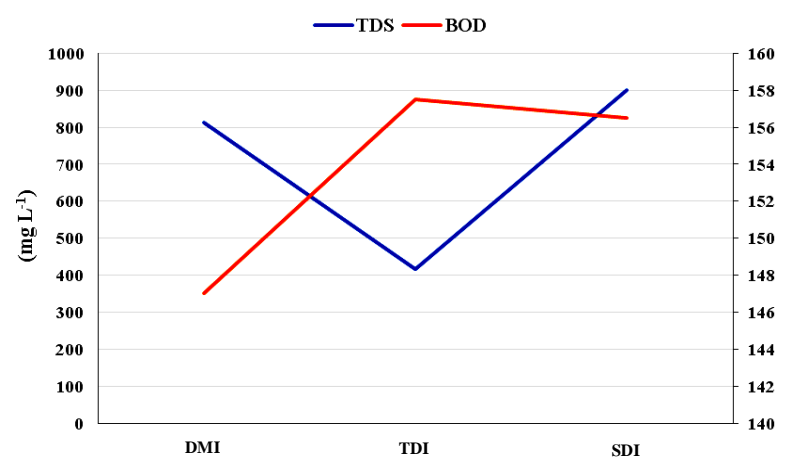

Figure 2. TDS and BOD of different industrial effluents samples

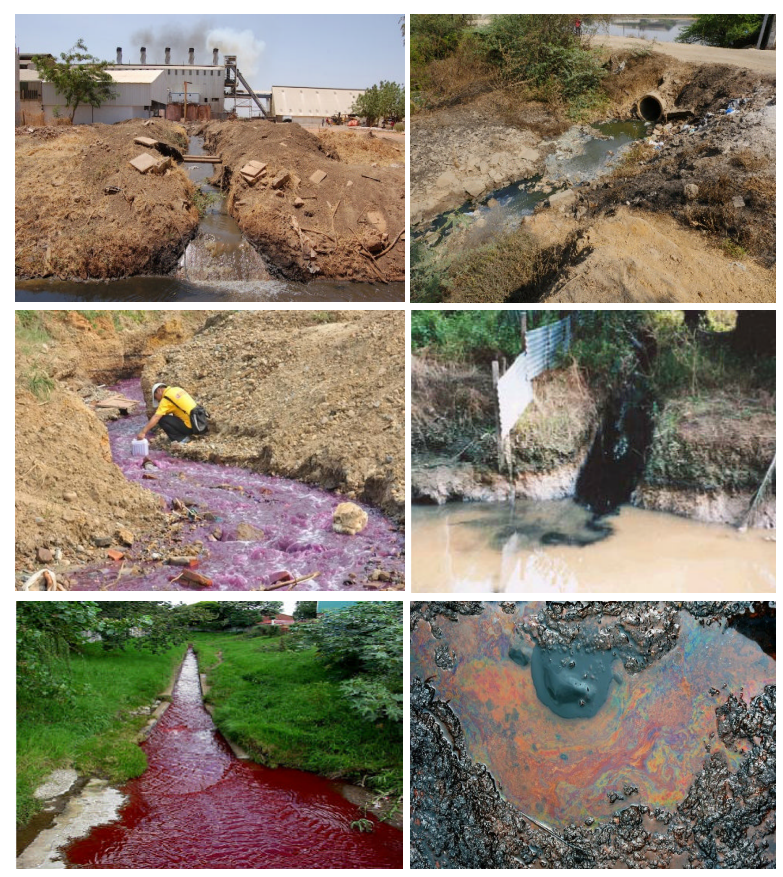

Figure 3. Dying industrial environmental pollution

The statistical results of BOD of the effluent based on industries are given in Fig. 2. The mean concentrations of BOD in the effluent samples of DMI, TDI, and SDI were found $147 \pm$ $4.14,157.5 \pm 0.51$ and $156.5 \pm 0.710 \mathrm{mg} \mathrm{L}^{-1}$, respectively. The BOD in studied effluent samples was two to three-fold higher than the recommended tolerance level stipulated by EPA for the discharge of industrial wastewater samples into rivers $\left(50 \mathrm{mg} \mathrm{L}^{-1}\right)$. These high levels of BOD values observed in wastewater samples of all the industries may be due to the high amount of organic matter from various chemicals used during the different processes of industries [36, 37]. Resulted data indicated that the variation among dying industries was statistically significant in all studied industries $(\mathrm{p}<0.05)$. These results of BOD (Fig. 2) showed that the discharge of wastewater samples from all dying industries and the activities by these industries remained almost constant throughout the sampling periods.

Heavy metals are a special group of trace elements that have been shown to create definite health hazards when taken up by plants. Under this group are included, $\mathrm{Cr}, \mathrm{Cd}, \mathrm{Pb}$, and $\mathrm{Ni}$. These are called heavy metals because in their metallic form, their densities are greater than $4 \mathrm{~g} / \mathrm{ml}[38,39]$. Analytical results of toxic metals $(\mathrm{Cd}, \mathrm{Cr}, \mathrm{Pb}$, and $\mathrm{Ni}$ ) in different dyes industrial wastewater samples of Hyderabad and Jamshoro, Pakistan showed that the total contents of $\mathrm{Cd}, \mathrm{Cr}, \mathrm{Pb}$, and $\mathrm{Ni}$ in wastewater samples of DMI, TDI and SDI varied in the range of $(0.130-0.916,0.134-1.522$, and $0.112-2.310), \quad(0.043-0.064, \quad 0.039-0.066$, and $0.040-0.054), \quad(0.233-0.501, \quad 0.091-0.456$, and $0.168-1.838)$, and $(0.250-0.480,0.096-0.568$, and $0.177-1.974) \mathrm{mg} \mathrm{L}^{-1}$, respectively (Fig. 4). The maximum levels of total $\mathrm{Cd}$ and $\mathrm{Ni}$ were found in effluent samples of SDI and the level of $\mathrm{Cd}$ and $\mathrm{Ni}$ contaminations may be varied in decreasing order as $\mathrm{SDI}>\mathrm{TDI}>\mathrm{DMI}$ (Fig 4). The $\mathrm{Cd}$ and Ni contents in effluent samples of all studied industries were higher than the WHO standard for $\mathrm{Cd}$, and $\mathrm{Ni}\left(0.01 \mathrm{mg} \mathrm{L}^{-1}, 0.10 \mathrm{mg} \mathrm{L}^{-1}\right)$ respectively. The maximum level of total $\mathrm{Cr}$ found in effluent samples of TDI and the level of $\mathrm{Cr}$ contamination may be varied in decreasing order as TDI > DMI > SDI (Fig. 4). The Cr contents in effluent samples of all studied industries were higher than the WHO standard for $\mathrm{Cr}\left(0.05 \mathrm{mg} \mathrm{L}^{-1}\right)$. The maximum level of total $\mathrm{Pb}$ found in effluent samples of SDI and the level of $\mathrm{Pb}$ contamination may be varied in decreasing order as SDI > DMI > TDI (Fig. 4). The possible sources of $\mathrm{Cd}, \mathrm{Cr}, \mathrm{Pb}$ and $\mathrm{Ni}$ in the wastewater samples of SDI may be the contaminated water used for the dissolving of dyes, leaching from a container in which dyes are prepared, contamination in dyes, the environmental pollutant or traffic dust because of local dyes [40]. Industries worker are performing all these activities along with the mainstream of market roads. Whereas, the heavy metals contamination sidewise the impurities in dyes might be the use of mordants, chemical reagents, cellulose fiber of clothes, heavy metal polluted water used for washing, etc. 


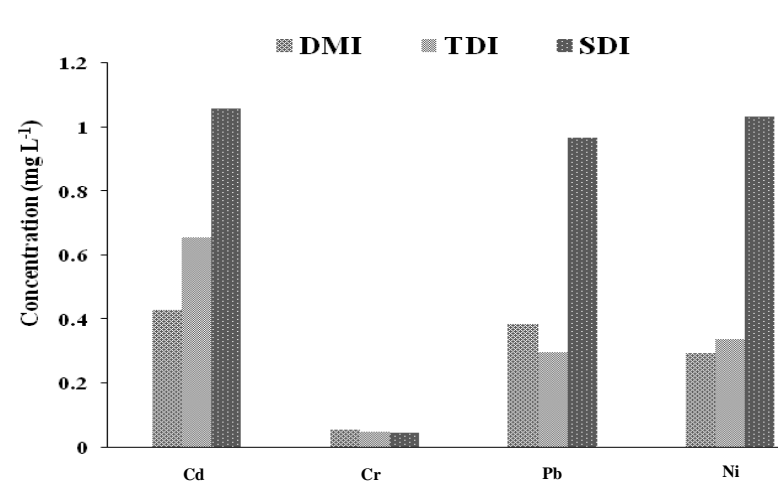

Figure 4. Concentration of toxic metals in different industrial effluents samples

\section{Conclusion}

It has been concluded that the $\mathrm{pH}$ of all studied industrial wastewater samples was neutral to basic might be due to the presence of different chemicals used in cleaning, color sticking, washing, and polymerization/dying process in these industries. TDS and EC of TDI effluent samples were lower than DMI and SDI might be due to the huge volume of water used for washing. The elevated contents of EC in DMI and SDI wastewater samples may be attributed to the high salinity and mineral contents in nearby water bodies. The EC of TDI effluent samples were found to be low as compared to wastewater samples of the other three industries ( $p>0.05$ ). The maximum level of EC was observed in effluent samples of SDI followed by DMI. It is because of the release of different chemical compounds along with dyes into their wastewater samples and may cause deterioration of drinking water quality. The BOD in studied effluent samples was two to three-fold higher than the recommended tolerance level stipulated by EPA for the discharge of industrial wastewater samples into rivers $\left(50 \mathrm{mg} \mathrm{L}^{-1}\right)$. These high levels of BOD values observed in wastewater samples of all the industries may be due to the high amount of organic matter from various chemicals used during the different processes of industries. The $\mathrm{Cd}, \mathrm{Cr}$, and $\mathrm{Ni}$ contents in effluent samples of all studied industries were higher than the WHO standard for $\mathrm{Cd}, \mathrm{Cr}$, and $\mathrm{Ni}\left(0.10,0.10\right.$, and $0.20 \mathrm{mg} \mathrm{L}^{-1}$, respectively). Comparative result of total $\mathrm{Cd}, \mathrm{Cr}$, $\mathrm{Pb}$, and $\mathrm{Ni}$ in small dying industrial effluent samples varied which might be due to change in environmental condition, strictly implication of regulation, the difference in the procedure for dying, etc.

\section{References}

1. M. Islam, and M. Mostafa, J. Env. Sci. Nat. Res., 11 (2018) 131. doi.org/10.3329/jesnr.v11i1-2.43380

2. V. Emongor, E. Nkegbe, B. Kealotswe, I. Koorapetse, S. Sankwasa and S. Keikanetswe, J. Appl. Sci., 5 (2005) 147. doi: 10.3923/jas.2005.147.150

3. M. Jaishankar, T. Tenzin, A. Naresh, Blessy B. Mathew, N. Krishnamurthy and N. Beeregowda, J. Interdis. Tox., 7 (2014) 60. doi: 10.2478/intox-2014-0009

4. J. A. Baig, T. G. Kazi, M.B Arain, H. I. Afridi, G.A Kandhro, R. A Sarfraz , M.K Jamal and A. Q Shah, J. Hazard. Mat., 166 (2009) 662. doi: 10.1016/j.jhazmat.2008.11.069

5. T. G. Kazi, M. B Araina, J. A Baig, M. K. Jamali, H. I. Afridi, N. Jalbani, R. A Sarfraz, A. Q Shah and A. Niaz, J. Sci. Tot. Environ., 407 (2009) 1019. doi: 10.1016/j.scitotenv.2008.10.013

6. J. A. Baig, T. G. Kazi, A. Q Shah, G. A. Kandhro, H. I. Afridi, M. B. Arain, M. K. Jamali and N. Jalbani, J. Ecotox. Environ. Safe., 73 (2010) 914.

doi: 10.1016/j.ecoenv.2010.01.002

7. H. Ali, J. Wates Air Soil Poll., 213 (2010) 251.

doi: 10.1007/s11270-010-0382-4

8. F. Shah, T. G. Kazi, H. I. Afridi, J. A. Baig, S. Khan, N. F. Kolachi, S. K. Wadhwa and A. Q. Shah, J. Sci. Tot. Environ., 408 (2010) 5325 .

doi: 10.1016/j.scitotenv.2010.07.091

9. G. M. Mastoi, S. G. S. Shah and M. Y. Khuhawar, J. Environ. Monit. Asses., 141 (2008) 287. doi.org/10.1007/s10661-007-9895-8

10. O. J. Hao, H. Kim and P. C. Chiang, J. Crit. Rev. Environ. Sci. Tech., 30 (2000) 449. doi.org/10.1080/10643380091184237

11. N. Abdel-Ghani and G. Elchaghaby, Int. J. Environ. Sci. Tech., 4 (2007) 451. doi.org/10.1007/BF03325980 
12. H. I. Afridi, T. G. Kazi, N. Kazi, M. K. Jamali, M. B. Arain, N. Jalbani, J. A. Baig and R. A. Sarfraz, J. Diab. Res. Clin. Prac., 80 (2008) 280.

doi: 10.1016/j.diabres.2007.12.021

13. N. Jalbani, T. G. Kazia, M. B. Arain, M. K. Jamali and H. I. Afridi, J. Chem. Spec. Bioav., 19 (2007) 163.

https://doi.org/10.3184/095422907X255884

14. R. Saratale, G. D. Saratale, D. C. Kalyani, J.

S. Chang and S. P. Govindwar, J. Biores. Tech., 100 (2009) 2493.

doi: 10.1016/j.biortech.2008.12.013

15. M. Solís, A. Solís, H. I. Pérez, N. Manjarrez and M. Flores, J. Proc. Biochem., 47 (2012) 1723.

doi I.org/10.1016/j.procbio.2012.08.014

16. P. Cunniff, Association of Official Analytical Chemists (AOAC) Official Methods of Analysis, (1996), AOAC.

doi: 10.4236/jep.2012.34040

17. R. P. Schwarzenbach, B. I. Escher, K. Fenner, T. B. Hofstetter, C. A. Johnson, U. Gunten and B. Wehrli, J. Sci., 313 (2006) 1072.

doi: $10.1126 /$ science. 1127291

18. C. J. Vörösmarty, P. B. McIntyre, M. O. Gessner and D. Dudgeon, J. Nat., 467 (2010) 555. doi.org/10.1038/nature09440

19. M. N. Chong, B. Jin, W. K. C. Christopher and C. Saint, J. Wate Res., 44 (2010) 2997. doi: 10.1016/j.watres.2010.02.039

20. D. H. K. Reddy, D. K. V. Ramana, K. Seshaiah and A. V. R. Reddy, J. Desalin., 268 (2011) 150.

doi.org/10.1016/j.desal.2010.10.011

21. D. H. K. Reddy, K. Seshaiaha, A. V. R. Reddy and S. M. Lee, J. Carboh. Poly., 88 (2012) 1077.

doi.org/10.1016/j.carbpol.2012.01.073

22. Z. Singh and P. Chadha, J. Occup. Med. Toxicol., 11 (2016) 39. doi:10.1186/s12995-016-0128-3

23. G. D. Aragão Umbuzeiro, H. Freeman, H. S. Warren, F. Kummrow and D. L. Claxton, $J$. Food Chem. Toxicol., 43 (2005) 49 doi: 10.1016/j.fct.2004.08.011

24. M. M. Rahman, Arsenic contamination incidents around the world, (2006), Csiro Publishing. https://books.google.com.pk/books?hl=en\&l r=\&id=izVjtgwO_8kC\&oi=fnd\&pg=PA3\&d q=Rahman,+M.M.,+et+al.+(2006)+Arsenic + Contamination+Incidents+around+the+Wo rld\&ots=8UlxYoAdG8\&sig=3FDf4YNla7Y p8hntAU6frExwy1g\#v=onepage\&q\&f=false

25. J. A. Baig, H. D. Memon, S. A. I. Bukhari, T. G. Kazi, H. I. Afridi, H. M. Naseer and L. Elci, J. AOAC Int., 100 (2017) 1062.

doi: 10.5740/jaoacint. 16-0398

26. P. R. Hunter, J. M Colford, M. W. LeChevallier, S. Binder and P. S. Berger, $J$. Emer. Infec. Dis., 7 (2001) 544.

https://wwwnc.cdc.gov/eid/articles/issue/7/7 /table-of-contents

27. M. L. Kile, E. A. Houseman, V. B. Carrie, T. Smith, Q. Quamruzzaman, M. Rahman, G. Mahiuddin and D. C. Christiani, J. Environ. Heal. Persp., 115 (2007) 889. doi: $10.1289 /$ ehp. 9462

28. T. Ohe, T. Watanabe and K. Wakabayashi, J. Mutat. Res., 567 (2004) 109. doi: 10.1016/j.mrrev.2004.08.003

29. H. A. Azeem, J. Bio. Pak., 155 (2009) 35. https://www.semanticscholar.org/paper/Anal ysis-of-industrial-waste-water-from-Kot-

Lakhpat-

Azeem/fbd9ce679a793817aa478bdfb6c0816 dc55a1e9c

30. A. Bafana, M. Jain, G. Agrawal, T. Chakrabarti, J. Chemo., 74 (2009) 1404. doi: 10.1016/j.chemosphere.2008.11.043

31. K. Bharathi and S. Ramesh, J. Appl. Water Sci., 3 (2013) 773.

doi.org/10.1007/s13201-013-0117-y

32. J. A. Baig, L. Elci, M. I. Khan, T. G. Kazi, J. AOAC Int., 97 (2014) 1421. doi: 10.5740/jaoacint.12-139

33. M. Bayramoglu, M. Kobya, O. T. Can and M. Sozbir, J. Sep. Purif. Tech., 37 (2004) 117.

doi: 10.1016/j.seppur.2003.09.002

34. N. K. Amin, J. Desal., 223 (2008) 152. doi.org/10.1016/j.desal.2007.01.203

35. U. Epa, , Guidelines for neurotoxicity risk assessment. Federal Register, 63 (1998) 26926.

https://19january2017snapshot.epa.gov/sites/ production/files/201411/documents/neuro_tox 
36. D. Dubber and N. F. Gray, J. Environ. Sci. Health, 12 (2010) 1595. doi: $10.1080 / 10934529.2010 .506116$

37. P. U. Singare, R. M. Mishra and M. P. Trivedi, J. Front. Sci., 3 (2012) 28. doi: $10.5923 /$ j.fs. 20120203.03

38. H. Ali, E. Khan and I. Ilahi, J. Chem., (2019) 28.

doi.org/10.1155/2019/6730305
39. A. Baysal, N. Ozbek and S. Akman, (ed. FSG Einschlag, L. Carlos), (2013) 145. doi:10.5772/52025

40. M. Tytła, Int. J. Environ. Res. Pub. Health, 13 (2019) 24.

doi.org/10.3390/ijerph16132430 